\title{
Pongamia as a Source of Biodiesel in India
}

\author{
Gaurav Dwivedi, Siddharth Jain, Mahendra Pal Sharma
}

Alternate Hydro Energy Centre, IIT Roorkee, Roorkee, India.

Email: gdiitr2005@gmail.com

Received May 19, 2011; revised June 2, 2011, accepted June 9, 2011.

\begin{abstract}
Pongamia Pinnata trees are normally planted along the highways, roads, canals to stop soil erosion. Billions of trees exist all over India. If the seeds fallen along road side are collected, and oil is extracted at village level expellers, few million tons of oil will be available for Lighting the Lamps in rural area. It is the best substitute for Kerosene. Since these are spread over a large area, collection of seeds for Biodiesel manufacture is not viable. (A compact plantation can support a Biodiesel plant. The seedlings of Pongamia can survive in 1.5 meters deep water submergence / inundation for five to six months duration at a stretch. There are nearly 30,000 square $\mathrm{km}$ of water reservoirs in India. This tree can be cultivated in our water storage reservoirs up to 1.5 meters depth and reap additional economic value from unused reservoir lands. The estimated annual production of oil from its seeds is about 50,000 $t$. The oil has not yet found any significant commercial application. But due to increase in awareness and growth in research in this area the Pongamia it can be developed as the alternative source of fuel by replacing diesel. In the present study attempt has been made to study the scope of Pongamia in India.
\end{abstract}

Keywords: Pongamia, Biodiesel, Viscosity, Density, Flashpoint

\section{Introduction}

India ranks 6th in terms of consumption of energy i.e. $3.5 \%$ of the total world's commercial energy. The current consumption of diesel in India is about 40 million tonnes (MT) $(40 \%$ of the total consumption of petroleum in the country) and is expected to reach 65 million tonnes (MT) by 2011-12, whereas the domestic production of crude oil and natural gas will be less as compared to demand. There is huge gap between demand and supply which is presently met by imports putting heavy burden of foreign exchange on the country. Production of biodiesel from oil and ethanol from sugar based resources are considered as the best substitute of diesel and gasoline respectively in the country. The waste and degraded land after reclamation can be used to grow the resource, produce oil and its conversion to biodiesel. The biodiesel are the monoalkyl ester of long chain fatty acids of vegetable oil or animal fats either from plant or animal. The biodiesel, when mixed with diesel up to $20 \%$ requires very little or no modification internal combustion engine and brings substantial reduction in the emission of unburned hydrocarbon by $30 \%$, carbon monoxide by $20 \%$ and particulate matters by $25 \%$ with no sulphur. The biodiesel has nearly $10 \%$ more oxygen which facilitates the combustion and enhances the cetane number (51).

\section{Cultivation of Oil Seed Plant in India}

Depending on climate and soil conditions, different nations are looking for different vegetable oils as substitute of diesel fuel: soybean oil in USA, rapeseed and sunflower oils in Europe, palm oil in south East Asia and coconut oil in Philippines is considered as substitutes for diesel fuels. In India, the demand for biodiesel for the year 2011-2012 has been estimated as 13.38 million tonnes considering $20 \%$ blends of biodiesel with diesel. The area required for growing the Jatropha plantation alone is about 11.19 Million hectares [1]. The use of edible oil resources like mustard, soya bean, sunflower, palm oil etc for biodiesel production put heavy competition with food and above that, the demand of edible oils is being met by importing from other countries. The non edible oil sources seem to be the only option for cultivation, oil extraction and biodiesel production on industrial scale for engine operation.

The various non edible sources are given in Table 1.

It is estimated that the potential availability of such oils in India is about 1 million tons per year. The most abundant oil sources are Sal, Mahua, Neem, Pongamia and Jatropha. Based on extensive research, Jatropha and Pongamia are been identified as the potential feedstocks for biodiesel production in near future. Table 2 gives the 
Table 1. Non edible oil sources [1].

\begin{tabular}{|c|c|c|}
\hline Family Name & Name of the plant & Uses \\
\hline \multirow{2}{*}{ Meliaceae } & Aphanamixis piolystachya (Wall.) Parker & Oil used for illumination \\
\hline & Azadirachta indica A. Juss & Oil used for illumination \\
\hline Barringtoniacea/Lecythidaceae & Barringtonia racemosa Roxb. (L.) Spreng. & The seed oil-illuminant-used in lamps \\
\hline \multirow{4}{*}{ Clusiaceae } & Calophyllum inophyllum L. C. apetalum Willd. & Seed oil-used for burning \\
\hline & Calophyllum polyanthum Wall. ex Choisy & Seed oil used for Lighting \\
\hline & Garcinia rubro-echinata Kosterm & Seed oil used for illuminant \\
\hline & Mesua ferrea L. & Seed oil used for illuminant \\
\hline \multirow{2}{*}{ Burseraceae } & Canarium strictum Roxb. & Resin is used as an illuminant. \\
\hline & C. zeylanicum (Retz.) Bl. (Native of Sri Lanka) & Oil used for lighting-illuminant, \\
\hline \multirow[b]{2}{*}{ Apocynaceae } & Cerbera manghas L. & Oil used as illuminant \\
\hline & $\begin{array}{l}\text { Caseabela thevetia (L.)Lippold Thevetia peru- } \\
\text { viana (Pers.) Merr. (Sometimes edible) }\end{array}$ & Seed oil used for burning \\
\hline \multirow{4}{*}{ Asteraeae } & Cirsum arvense (L.) Scop. (Native of Europe) & Oil used as illuminant \\
\hline & Calophyllum inophyllum & Oil used as illuminant \\
\hline & Calotropis & Oil used as illuminant \\
\hline & Euphorbia tirucalli & Oil used as illuminant \\
\hline Mimosaceae & Entada rheedei Spreng. & Oil used in lamps \\
\hline Papaveraceae & Argemone mexicana L. & Oil used as illuminant \\
\hline \multirow{2}{*}{ Hernandiaceae } & Hernandia ovigera & Seed kernel for fuel and oil as, essential oils \\
\hline & Levea brasiliensis & Seed kernel- for fuel and oil as, essential oils \\
\hline Malvaceae & Hibiscus cannabinus L. & Oil used for lighting \\
\hline Flacourtiaceae & Hydnocarpus alpina Wight & Oil used for lighting \\
\hline \multirow{5}{*}{ Euphorbiaceae } & Jatropha curcas L. & Seed oil used for Illuminant \\
\hline & J. gossypifolia L. & Seed oil used for lamps \\
\hline & Joannesia princeps Vell & Seed oil used for fuel \\
\hline & $\begin{array}{l}\text { Putranjiva roxburghii Wall. Drypetes roxburghii } \\
\text { (Wall.) Hurusawa }\end{array}$ & $\begin{array}{l}\text { Seed kernel oil used for burning, Kernel yield an essential } \\
\text { oil. }\end{array}$ \\
\hline & Ricinus communis Linn. & Seed oil used for fuel, Seeds yield castor oil, \\
\hline Lauraceae & Neolitsea umbrosa (Nees) Gamble & Fruit oil used for burning \\
\hline Sapotaceae & Palaquium ellipticum (Dalz.) Baill. & Seed oil used for lighting, fatty oils used for soap making. \\
\hline Fabaceae & $\begin{array}{l}\text { Pongamia glabra Vent. Derris indica (Lank.) } \\
\text { Bennett. }\end{array}$ & Seed oil used for illuminant \\
\hline Anacardiaceae & Rhus semialata Murr. & $\begin{array}{l}\text { Vegetable wax extracted from fruits used for making can- } \\
\text { dles) }\end{array}$ \\
\hline Salvadoraceae & Salvadora oleoides Decne & Seed fat used for candle making \\
\hline Sterculiaceae & Sterculia foetida Linn. & Seed oil used for illuminant \\
\hline Meliaceae & $\begin{array}{l}\text { Xylocarpus moluccensis (Lam) Roem. } \\
\text { Carapa moluccensis Lam. }\end{array}$ & Seed oil used for illuminant \\
\hline Myristicaceae & Gymnacranthera canarica Warb. & Seed fat used for burning \\
\hline Caesalpiniaceae & Tamarindus indica L. & $\begin{array}{l}\text { Seed kernels-burning lamps, fatty oil of seeds is used in } \\
\text { making paints }\end{array}$ \\
\hline Caprifoliaceae & $\begin{array}{l}\text { Viburnum coriaceum Blume (Nepalese use it for } \\
\text { edible purposes) }\end{array}$ & Seed oil used for burning \\
\hline Celastraceae & Celastrus paniculatus Willd. & Seed oil used for illuminant \\
\hline Lauraceae & Neolitsea cassia (Linn.) Kostermans Syn. & Kernel oil used burning \\
\hline Icacinaceae & Sarcostigma kleinii Wight \& Arn. & Seed oil used for illuminant \\
\hline Dipterocarpaceae & Vateria indica Linn. (Non-edible) & Seeds yield semi solid fat used for making candles. \\
\hline
\end{tabular}


Table 2. Production of non-edible oil [1].

\begin{tabular}{crcc}
\hline S. No. & Botanical Name & Local Name & Annual Productivity (Tons) \\
\hline 1. & Jatropha curcas & Ratanjyot & 15,000 \\
2. & Pongamia Pinnata & Karanja & 55,000 \\
\hline
\end{tabular}

oil productivity of the most important non-edible oils resources in India.

It is seen that Pongamia Pinnata has higher productivity as compared to jatropha.

\section{Pongamia as a Source of Biodiesel}

Self-reliance in energy is vital for overall economic development of India and other developing countries of the world. The need to search for alternative renewable, safe and non polluting sources has been accords top priority. Further, uncertain supplies and frequent price hikes of fossil fuels in the international market are also posing serious economic threats for developing countries. Amongst the various non edible oil seed crops, Jatropha and pongamia plant is considered as the sole resources that can meet the growing demand of biodiesel in India due to their high productivity and less maturity cycle. Out of the two only Pongamia Pinnata will be considered in the present paper. Pongamia Pinnata found as one of the most suitable non edible oil plant species in India due to its good $\mathrm{N}_{2}$ fixing ability and not grazable eatable by animal. It can be grown in water logged, saline and alkaline soil, waste land/ fellow land and can withstand harsh agro climates. It is a medium sized evergreen tree with spreading crown and a short bole. The tree is planted in for shade and grown as ornamental tree. The seed contain $30 \%$ - $40 \%$ oil. The natural distribution is along the coasts and riverbanks in lands are native to the Asian subcontinent. It can also be cultivated along the roadsides, canal banks and open farm lands. It is a preferred species for controlling soil erosion. Its root, bark, leaves, sap, and flowers also have medicinal properties and are traditionally used as medicinal plants. The seeds are largely used to extract oil known as 'Karanja oil'.The fuel properties of Pongamia is compared with petroleum diesel as shown in Table 3.

In addition the same oil is used as fuel for cooking and lightening lamps. The oil is also used as a lubricant, water-paint binder, pesticide, and in soap making and tanning industries [2]. The crude oil is yellow orange to brown in colour, which thickens on standing. It has a bitter taste, disagreeable odour, and is non edible. The oil is known to have value in folk medicine for the treatment of rheumatism, as well as human and animal skin diseases. It is effective in enhancing the pigmentation of skin affected by leucoderma or scabies. Incorporation of leaves and the presscake used traditionally for improving soil fertility as leaves and cake are good sources of fixed nitrogen. Biologically dried leaves are used as an insect repellent in stored grains. The press cake, when applied to the soil, has pesticidal value, particularly against nematodes.

\subsection{Botanical Features}

Pongamia pinnata (Leguminoceae, subfamily Papilionoideae) is a medium sized tree that about $7-8$ meters high with a trunk diameter of more than $50 \mathrm{~cm}$. The trunk is generally short with thick branches spreading into a dense hemispherical crown of dark green leaves. The alternate, compound pinnate leaves consist of 5 or 7 leaflets arranged in 2 or 3 pairs, and a single terminal leaflet. Leaflets are 5 - $10 \mathrm{~cm}$ long, 4 - $6 \mathrm{~cm}$ wide, and pointed at the tip. Flowers are pink, light purple, or white. Pods are elliptical; (3 - $6 \mathrm{~cm}$ long and $2-3 \mathrm{~cm}$ wide) thick walled, and usually contain a single seed as shown in Figure 1.

\subsection{Botanical Description of Pongamia Pinnata [3]}

- Fast growing, medium sized legume tree

- Height: 7 - 10 m, stem diameter: 50 - 80 cm

- Smooth grey-brown bark with vertical fissuring

- Leaves compound, pinnate and alternate

- Mature leaves glossy dark green above, pale below

- Flowers white, pink or lavender pea-like blossoms, which bloom late spring/early summer

- Seeds are $1.5 \mathrm{~cm}$ long, light brown, oval and contained in clusters of brown, eye-shaped pods

- Reproduces via seeds but can be cultivated from root suckers or stem cuttings

- Yields from 9 to $90 \mathrm{~kg}$ seed/tree/annum

- Can produce up to $40 \%$ solvent extractable oil per seed

- Approximately $50 \%$ of oil is C18:1, which is suitable for biodiesel production (low cloud point)

- Nodulates with Bradyrhizobium; spherical nodule

- Chromosome number: 22

It grows at an altitude of about 1200 m having annual rainfall of 500 to $2500 \mathrm{~mm}$. Pongamia pinnata is an alkaline/saline and drought tolerant species. It sheds its leaves in April ( $4^{\text {th }}$ month) and new leaves start from May ( $5^{\text {th }}$ month) and onwards. Flowers appear in April ( $4^{\text {th }}$ month) to June ( $6^{\text {th }}$ month) and its pods ripe during March ( $3^{\text {rd }}$ month) to May ( $5^{\text {th }}$ month) of the following year. Seed ripe during February ( $2^{\text {nd }}$ month) to May ( $5^{\text {th }}$ 
Table 3. Selected fuel properties for petrodiesel \& pongamia oil methyl ester [2].

\begin{tabular}{lcc}
\hline Property & $\begin{array}{c}\text { Pongamia oil } \\
\text { methyl ester }\end{array}$ & Petroleum diesel \\
\hline Viscosity (cp) $\left(30^{\circ} \mathrm{C}\right) 52.6$ & 5.51 & 3.60 \\
Specific gravity $\left(15^{\circ} \mathrm{C} / 4^{\circ} \mathrm{C}\right)$ & 0.917 & 0.841 \\
Solidfying Point $\left({ }^{\circ} \mathrm{C}\right)$ & 2 & 0.14 \\
Cetane Value & 51 & 47.8 \\
Flash Point $\left({ }^{\circ} \mathrm{C}\right)$ & 110 & 80 \\
Carbon Residue $(\%)$ & 0.64 & 0.05 \\
Distillation $\left({ }^{\circ} \mathrm{C}\right)$ & $284-295$ & 350 \\
Sulfur $(\%)$ & $0.13-0.16$ & 1.0 \\
Acid Value & $1.0-38.2$ & - \\
Saponification Value & $188-198$ & - \\
Iodine Value & $90.8-112.5$ & - \\
Refractive Index $\left(30^{\circ} \mathrm{C}\right)$ & 1.47 & - \\
\hline
\end{tabular}

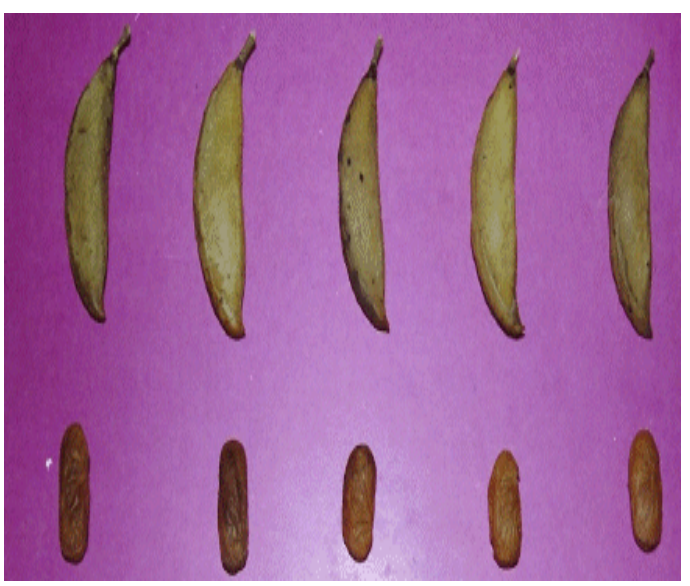

Figure 1. Seed of pongamia [4].

month) as given in Table 4.

\subsection{Ecology of Pongamia Pinnata}

Pongamia pinnata native to humid and subtropical environments, and thrive in areas with annual rainfall ranging from 500 to $2500 \mathrm{~mm}$. in its natural habitat, Matured trees can withstand water logging and slight frost is not found above $600 \mathrm{~m}$. Pongamia can grow on most soil types ranging from stony to sandy to clay, including Himalayan foothills and so is common along waterways or seashores, with its roots in fresh or salt water. Highest growth rates are observed on well drained soils with assured moisture.

\subsection{Distribution}

The natural distribution of pongamia is along the coasts and river banks in India and Burma. It is native to the Asian subcontinent, and the species is introduced to hu-
Table 4. Growth pattern of Pongamia pinnata [4].

\begin{tabular}{|c|c|c|c|c|c|c|c|c|}
\hline $\begin{array}{ll}\text { Month } & \text { No. } \\
\text { Stage }\end{array}$ & 2 & 3 & 4 & 5 & 6 & 7 & 8 & 12 \\
\hline Seed ripen & & & & & & & & \\
\hline Pods ripen & & & & & & & & \\
\hline Flowers & & & & & & & & \\
\hline Fruits & & & & & & & & \\
\hline Leaf fall & & & & & & & & \\
\hline New leaf & & & & & & & & \\
\hline
\end{tabular}

mid tropical lowlands in the, Malaysia, Australia, the Seychelles, the United States and Indonesia [5].

\subsection{Chemical Composition of Pongamia Oil}

The seeds of Pongamia pinnata contain 30 to $40 \%$ oil which is thick, reddish brown in colour oil known as Pongam/Pongamol/Hongay oil which can be converted to biodiesel by transesterification with methanol in the presence of $\mathrm{KOH}$. FFA composition of pongamia seed oil which shows that the oil has $20.5 \%$ saturated and $79.4 \%$ unsaturated long chain fatty acids The major mono unsaturated fatty acid is oleic acid (46\%) linoleic acid $(27.1 \%)$ and linolenic acid (6.3\%) which constitutes the total polyunsaturated fatty acids. Low molecular weight fatty acids such as lauric and capric acids occur in very small amount of about $0.1 \%$ each.

\subsection{Cultivation of Plants}

Pongamia can be easily established by direct seeds or by planting nursery-raised seedlings or stem cuttings of 1 - 2 $\mathrm{cm}$. In India, the seeding season is April June, and the seed yield per tree ranges from about 10 - $50 \mathrm{~kg}$. Seeds, requiring no treatment before sowing, remain viable for about a year when stored in air-tight containers. Seed germinates within two weeks of sowing. Seedlings attain a height of $25-30 \mathrm{~cm}$ in their first growing season.

\subsection{Transplantation}

Transplanting to the field should occur at the beginning of the next rainy season when seedlings attain $60 \mathrm{~cm}$ height. Seedlings have large root systems and so the soil should be retained around the roots during transplantation [6]. The spacing adopted in avenue plantings is about $8 \mathrm{~m}$ between plants. In block planting, the spacing can range from $2 \times 2$ to $5 \times 5 \mathrm{~m}$. Pongamia seedlings withstand shade very well and can be inter planted in existing tree stands.

\subsection{Management}

Pongamia should be grown in full sun or partial shade on well-drained soil low maintenance tree once established 
becomes resistant to high winds and drought but is susceptible to temperatures below $0^{\circ} \mathrm{C}$. Pongamia will show nutritional deficiencies if grown on soil with a $\mathrm{pH}$ above 7.5 .

\section{Uses}

\subsection{Soil Improver}

Addition of leaves and the seed cake into soils improves fertility. Decomposed flowers are valued in the tropics as rich nutrition for special plants, especially when grown in greenhouse.

\subsection{Nitrogen Fixing}

Nodulation is reported in pongamia. In nurseries and fields the presence of nodules on uninoculated pongamia seedlings is common. Therefore, this species may not be specific in its Rhizobium strain requirement [7]. It nodulates and fixes atmospheric nitrogen with Rhizobium of the cowpea group.

\subsection{Ornamental}

Pongamia pinnata is often planted in homesteads as an ornamental tree and in avenue plantings, roadsides, streams and canal banks [8]. However the large amounts of flowers, leaves and pods that it regularly sheds make it not very suitable for this purpose.

\subsection{Shade or Shelter}

Grass grows normally beneath the tree so it has been planted for shade in pastures. Pongamia pinnata is grown as a windbreak for tea plantation in Sri Lanka.

\subsection{Erosion Control}

A preferred species for controlled soil erosion and binding sand dunes because of its extensive network of lateral roots.

\subsection{Reclamation}

Because it tolerates moderate levels of salinity, Pon- gamia is an ideal candidate for recovering a variety of wastelands such as saline soil reclamation. It is also used in reforestation of marginal lands.

\section{Biodiesel Scenario and Land Requirement in India}

As India is deficient in edible oils, non-edible oils become the main choice for biodiesel. Generally, a blend of $5 \%$ to $20 \%$ is used in India $\left(\mathrm{B}_{5}-\mathrm{B}_{20}\right)$ [9]. Indian oil corporation (IOC) has taken up Research and Development work to establish the parameters for the production and use of biodiesel in its R\&D centre at Faridabad Table 5 gives the requirements for different blends up to B20
Table 5. The biodiesel and land requirement in India for future [9].

\begin{tabular}{cccc}
\hline \multirow{2}{*}{ Year } & \multirow{2}{*}{$\begin{array}{c}\text { Diesel demand } \\
(\mathrm{MT})\end{array}$} & $\begin{array}{c}\text { Biodiesel requirement } \\
(\mathrm{MT})\end{array}$ & $\begin{array}{c}\text { Area requirement } \\
(\text { Mha })\end{array}$ \\
\cline { 3 - 4 } & & $\mathrm{BD}_{20}$ & $\mathrm{BD}_{20}$ \\
\hline $2007-08$ & 60.18 & 12.0 & 21.0 \\
$2008-09$ & 90.27 & 18.0 & 30.0 \\
$2009-10$ & 95.23 & 19.0 & 31.7 \\
$2010-11$ & 100.47 & 20.1 & 33.5 \\
$2011-12$ & 106.00 & 21.2 & 35.3 \\
$2012-13$ & 111.83 & 22.3 & 37.2 \\
$2013-14$ & 117.98 & 23.6 & 39.3 \\
$2014-15$ & 124.47 & 24.9 & 41.5 \\
$2015-16$ & 131.31 & 26.2 & 43.7 \\
$2016-17$ & 138.54 & 27.7 & 46.1 \\
$2017-18$ & 146.16 & 29.2 & 48.7 \\
$2018-19$ & 154.19 & 30.8 & 51.4 \\
$2019-20$ & 162.67 & 32.5 & 54.2 \\
\hline
\end{tabular}

which gives the engine performance similar to diesel in terms of power output \& other parameters.

\section{Conclusions}

Demand for transport fuel is increasing unabatedly in India. On the other hand there are frequent hikes of prices of fossil fuel and uncertain supply in international market. To minimize the import of crude oil we must go for Bio fuels which are renewable and eco friendly. Pongamia oil may stands as Bio-diesel which is renewable, safe and non-polluting. It holds great promise to the rural sectors of India to meet the energy and organic fertilizer requirements. Of course researchers are to be carried out on Pongamia to standardize agro-technology, low cost and efficient mechanical device to expel oil, to find out the economics, high yielding and high oil content varieties suitable to the different agro-climates of India. In that way researchers are also to be carried out value addition on by products of Pongamia oil. By planting Pongamia on roadsides, river bank, on the two sides of irrigation canals, marginal and degraded soils. India will able to produce tons of Bio-diesel and organic fertilizers (Oil cake) in near future.

\section{REFERENCES}

[1] S. Jain and M. P. Sharma, "Prospects of Biodiesel from Jatropha in India: A Review," Renewable and Sustainable Energy Reviews, Vol.14, No. 2, 2010, pp. 763-771. doi:org/10.1016/j.rser.2009.10.005

[2] S. P.Wani and T. K. Sreedevi, "Pongamia's Journey from Forest to Micro-Enterprise for Improving Livelihoods," 
Andhra University Press, Andhra Pradesh, 1999.

[3] P. Gogoi, “Assam, Pongamia Oil—A Promising Source of Bio-Diesel,” Assam University Press, Assam, 2008.

[4] V. Kesari, A. Das and L. Rangan, "Physico-Chemical Characterization and Antimicrobial Activity from Seed Oil of Pongamia Pinnata a Potential Biofuel Crop,” Bio Mass and Bio Energy, Vol. 34, No. 1, 2010, pp. 108-115. doi:org/10.1016/j.biombioe.2009.10.006

[5] S. Sangwan, D. V. Rao and R. A. Sharma, "A Review on Pongamia Pinnata (L.) Pierre: A Great Versatile Leguminous Plant," Nature and Science, Vol. 8, 2010, pp. 1 $-11$.

[6] N. Mukta, Y. Sreevalli, "Propagation Techniques, Evaluation and Improvement of the Biodiesel Plant, Pongamia pinnata (L.) Pierre-A Review,” Industrial Crops and Products, Vol. 31, No. 1, 2010, pp. 1-12.

doi:org/10.1016/j.indcrop.2009.09.004
[7] W. S. Eipesona, J. R. Manjunathab, P. Srinivasb and T. C. S. Kanya, "Extraction and Recovery of Karanjin: A Value Addition to Karanja (Pongamia Pinnata) Seed Oil,” Industrial Crops and Products, Vol. 32, No. 2, 2010, pp. 118-122.

[8] H. V. Kamath, I. Regupathi and M. B. Saidutta, “Optimization of Two Step Karanja Biodiesel Synthesis under Microwave Irradiation,” Fuel Processing Technology, Vol. 92, No. 1, 2011, pp. 100-105. doi:org/10.1016/j.fuproc.2010.09.003

[9] S. L. Badole and S. L. Bodhankar, “Antidiabetic Activity of Cycloart-23-ene-3 $\beta$, 25-diol (B2) Isolated from Pongamia Pinnata (L. Pierre) in Streptozotocin Nicotinamide Induced Diabetic Mice,” European Journal of Pharmacology, Vol. 632, No. 1-3, 2010, pp. 103-109. doi:org/10.1016/j.ejphar.2010.01.019 